\title{
$\mathrm{Ni}_{2} \mathrm{P} / \mathrm{SiO}_{2}$ 和 $\mathrm{Ni} / \mathrm{SiO}_{2}$ 催化剂甘油氢解反应性能比较: 催化剂活性及 产物选择性影响因素的探讨
}

\author{
黄金花，陈吉祥* \\ 天津大学化工学院催化科学与工程系天津市应用催化科学与工程重点实验室, 天津 300072
}

\begin{abstract}
摘要: 采用浸渍法及程序升温还原法制备了 $\mathrm{Ni}_{2} \mathrm{P} / \mathrm{SiO}_{2}$ 和 $\mathrm{Ni} / \mathrm{SiO}_{2}$ 催化剂, 利用 $\mathrm{N}_{2}$ 吸附-脱附、 $\mathrm{X}$ 射线衍射、 $\mathrm{X}$ 射线苂光、 $\mathrm{CO}$ 化 学吸附、氢气程序升温脱附及氨气程序升温脱附等手段对催化剂进行了表征并用于甘油氢解反应. 结果表明, $\mathrm{Ni}_{2} \mathrm{P} / \mathrm{SiO}_{2}$ 和 $\mathrm{Ni} / \mathrm{SiO}_{2}$ 具有相近的表面 $\mathrm{Ni}$ 密度, 但前者表面酸中心和表面氢物种 (包括吸附氢和溢流氢) 密度明显更高, 且在甘油氢解反应中 的活性也更高, 这与其酸性中心与金属中心之间的协同作用有关. $\mathrm{Ni}_{2} \mathrm{P} / \mathrm{SiO}_{2}$ 催化剂上主要产物为 1,2 -丙二醇及 1 -丙醇, 而 $\mathrm{Ni} / \mathrm{SiO}_{2}$ 催化剂上主要产物为 1,2 -丙二醇、乙二醇和乙醇. 提高反应温度和 $\mathrm{H}_{2}$ 压力不能促进 $\mathrm{Ni}_{2} \mathrm{P} / \mathrm{SiO}_{2}$ 上乙醇和乙二醇的生成, 但促进了 1,2-丙二醇进一步氢解转化为 1-丙醇. 由此可见, $\mathrm{Ni}_{2} \mathrm{P} / \mathrm{SiO}_{2}$ 具有较强的 $\mathrm{C}-\mathrm{O}$ 键断裂活性及较弱的 $\mathrm{C}-\mathrm{C}$ 键断裂活性, 这可能分别与其较多酸性中心和电子及几何结构性质密切相关.
\end{abstract}

关键词: 甘油氢解；磷化镍；瀪；酸性；电子和几何性质

中图分类号: O643 文献标识码: A

收稿日期: 2011-11-28. 接受日期: 2012-02-08.

*通讯联系人. 电话: (022)27890865; 传真: (022)87894301; 电子信箱: jxchen@tju.edu.cn

基金来源: 国家自然科学基金 (21176177).

本文的英文电子版(国际版)由Elsevier出版社在ScienceDirect上出版(http://www.sciencedirect.com/science/journal/18722067).

\section{Comparison of $\mathrm{Ni}_{2} \mathrm{P} / \mathrm{SiO}_{2}$ and $\mathrm{Ni} / \mathrm{SiO}_{2}$ for Hydrogenolysis of Glycerol: A Consideration of Factors Influencing Catalyst Activity and Product Selectivity}

\author{
HUANG Jinhua, CHEN Jixiang* \\ Tianjin Key Laboratory of Applied Catalysis Science and Technology, Department of Catalysis Science and Engineering, \\ School of Chemical Engineering and Technology, Tianjin University, Tianjin 300072, China
}

\begin{abstract}
Ni}_{2} \mathrm{P} / \mathrm{SiO}_{2}$ and $\mathrm{Ni} / \mathrm{SiO}_{2}$ catalysts were prepared for the hydrogenolysis of glycerol, and their structural properties were characterized by $\mathrm{N}_{2}$ sorption, X-ray diffraction, X-ray fluorescence, $\mathrm{CO}$ chemisorption, $\mathrm{H}_{2}$ temperature-programmed desorption, and $\mathrm{NH}_{3}$ temperature-programmed desorption. It was found that $\mathrm{Ni}_{2} \mathrm{P} / \mathrm{SiO}_{2}$ had a similar density of exposed $\mathrm{Ni}$ sites as $\mathrm{Ni} / \mathrm{SiO}_{2}$, while $\mathrm{Ni}_{2} \mathrm{P} / \mathrm{SiO}_{2}$ had much larger amount of acid sites and surface hydrogen species than $\mathrm{Ni} / \mathrm{SiO}_{2} . \mathrm{Ni}_{2} \mathrm{P} / \mathrm{SiO}_{2}$ was more active than $\mathrm{Ni} / \mathrm{SiO}_{2}$ in the hydrogenolysis of glycerol. This is attributed to the synergism between acid and metal sites on $\mathrm{Ni}_{2} \mathrm{P} / \mathrm{SiO}_{2}$. Glycerol was mainly converted to 1,2-propanediol over $\mathrm{Ni}_{2} \mathrm{P} / \mathrm{SiO}_{2}$, while it was mostly converted to not only 1,2-propanediol but also ethylene glycol and ethanol over $\mathrm{Ni} / \mathrm{SiO}_{2}$. The formation of ethylene glycol and ethanol on $\mathrm{Ni} / \mathrm{SiO}_{2}$ is attributed to the $\mathrm{C}-\mathrm{C}$ bond cleavage catalyzed by metallic $\mathrm{Ni}$ rather than weak acidity. In addition, temperature and $\mathrm{H}_{2}$ pressure increase did not promote the formation of ethylene glycol and ethanol on $\mathrm{Ni}_{2} \mathrm{P} / \mathrm{SiO}_{2}$. Instead they mainly promoted the further conversion of 1,2-propanediol to form 1-propanol. Thus, $\mathrm{Ni}_{2} \mathrm{P} / \mathrm{SiO}_{2}$ was more active for the cleavage of $\mathrm{C}-\mathrm{O}$ bonds and less active for the cleavage of $\mathrm{C}-\mathrm{C}$ bonds than $\mathrm{Ni} / \mathrm{SiO}_{2}$. We suggest that the higher activity of $\mathrm{Ni}_{2} \mathrm{P} / \mathrm{SiO}_{2}$ for the cleavage of $\mathrm{C}-\mathrm{O}$ bonds can be ascribed to its acidity, while its lower activity for the cleavage of $\mathrm{C}-\mathrm{C}$ bonds may be mainly related to its electronic and geometrical properties.
\end{abstract}

Key words: glycerol hydrogenolysis; nickel phosphide; nickel; acidity; electronic and geometrical properties 
English edition available online at Elsevier ScienceDirect (http://www.sciencedirect.com/science/journal/18722067).

Biomass is an environmentally friendly renewable resource, from which various useful chemicals and fuels can be produced [1]. Now, the transesterification of vegetable oils and animal fats with methanol to biodiesel has been commercialized, during which glycerol is co-produced. A rapid development of biodiesel processes leads to an oversupply of glycerol in the market. It is very significant to convert glycerol to more valuable chemicals. The hydrogenolysis of glycerol into high-value diols (1,2-propanediol (1,2-PDO), 1,3-propanediol (1,3-PDO), and ethylene glycol $(\mathrm{EG}))$ is very attractive among the routes for using glycerol $[2,3]$.

Noble metals (such as $\mathrm{Ru}$ [4-8], $\mathrm{Ni}$ [9-11], and $\mathrm{Cu}$ [12]) catalysts have been applied to the hydrogenolysis of glycerol. $\mathrm{Cu}$-based catalysts gave the products 1,2-PDO and 1,3-PDO via the cleavage of $\mathrm{C}-\mathrm{O}$, while $\mathrm{Ru}$ and Ni-based catalysts also gave the degradation products (EG and ethanol) via the cleavage of $\mathrm{C}-\mathrm{C}$ bonds. When $\mathrm{Ru}$ and Ni-based catalysts were combined with acid catalysts, the cleavage of $\mathrm{C}-\mathrm{O}$ bonds via dehydration/hydrogenation was promoted while the cleavage of $\mathrm{C}-\mathrm{C}$ bonds was partially restrained.

It is known that the $\mathrm{Ni}_{2} \mathrm{P}$ phase has both acid and metal functions [13]. There is an electron transfer from Ni to $\mathrm{P}$ in $\mathrm{Ni}_{2} \mathrm{P}$, which leads to the $\mathrm{Ni}$ site possessing a small positive charge [14]. Thus, the structural properties of $\mathrm{Ni}_{2} \mathrm{P}$ are very different from that of metallic Ni. This may result in different performance of $\mathrm{Ni}$ and $\mathrm{Ni}_{2} \mathrm{P}$ catalysts in the hydrogenolysis of glycerol, and the study of this difference can provide information about the relationship between the catalyst structure and reactivity. To our knowledge, there are no related reports on the application of $\mathrm{Ni}_{2} \mathrm{P}$ in the hydrogenolysis of glycerol.

$\mathrm{SiO}_{2}$ was used as support to prepare $\mathrm{Ni}_{2} \mathrm{P} / \mathrm{SiO}_{2}$ in this work to reduce the effect of the support. For comparison $\mathrm{Ni} / \mathrm{SiO}_{2}$ was also prepared. The factors that influence the catalyst performance in the hydrogenolysis of glycerol are discussed in association with the structural properties of $\mathrm{Ni}_{2} \mathrm{P} / \mathrm{SiO}_{2}$ and $\mathrm{Ni} / \mathrm{SiO}_{2}$.

\section{Experimental}

\subsection{Catalyst preparation}

Commercial spherical silica (B-type, Qingdao Haiyang Chemicals Co., Ltd., China. BET specific surface area = $548 \mathrm{~m}^{2} / \mathrm{g}$ ) was used as support. Before using, silica particles with 20-40 mesh were obtained by triturating and sieving. $\mathrm{Ni}_{2} \mathrm{P} / \mathrm{SiO}_{2}$ was prepared by the temperature-programmed reduction (TPR) method [15]. Firstly, the precursor of
$\mathrm{Ni}_{2} \mathrm{P} / \mathrm{SiO}_{2}$ was prepared by the impregnation method. Silica was incipiently impregnated with an aqueous solution of $\mathrm{NH}_{4} \mathrm{H}_{2} \mathrm{PO}_{4}$ and $\mathrm{Ni}\left(\mathrm{NO}_{3}\right)_{2}$, followed by drying at $393 \mathrm{~K}$ for $12 \mathrm{~h}$ and calcination at $823 \mathrm{~K}$ for $5 \mathrm{~h}$. Secondly, $\mathrm{Ni}_{2} \mathrm{P} / \mathrm{SiO}_{2}$ was prepared from the precursor by TPR using the following program: heating from 293 to $523 \mathrm{~K}$ at $10 \mathrm{~K} / \mathrm{min}$ and from 523 to $923 \mathrm{~K}$ at $1 \mathrm{~K} / \mathrm{min}$ and then maintaining $923 \mathrm{~K}$ for $3 \mathrm{~h}$. The $\mathrm{H}_{2}$ (>99.9\%) flow was set at $290 \mathrm{ml} / \mathrm{min}$ per gram of precursor. The prepared catalyst was passivated in a $0.5 \% \mathrm{O}_{2} / \mathrm{N}_{2}$ flow for $10 \mathrm{~h}$. $\mathrm{Ni} / \mathrm{SiO}_{2}$ was prepared by the impregnation method. Silica was incipiently impregnated with an aqueous solution of $\mathrm{Ni}\left(\mathrm{NO}_{3}\right)_{2}$, followed by drying at 393 $\mathrm{K}$ for $12 \mathrm{~h}$ and calcination at $823 \mathrm{~K}$ for $5 \mathrm{~h}$. The prepared $\mathrm{Ni} / \mathrm{SiO}_{2}$ precursor was reduced at $723 \mathrm{~K}$ for $40 \mathrm{~min}$ to prepare $\mathrm{Ni} / \mathrm{SiO}_{2}$.

\subsection{Catalyst characterization}

X-ray diffraction (XRD) patterns were obtained on a D8 Focus powder diffractometer operated at $40 \mathrm{kV}$ and $40 \mathrm{~mA}$ using $\mathrm{Cu} K_{\alpha}$ radiation $(\lambda=0.15406 \mathrm{~nm}) . \mathrm{N}_{2}$ adsorption-desorption isotherms were obtained on a Quantachrome NOVA-2000 apparatus at $77 \mathrm{~K}$. The Brunauer Emmett Teller (BET) equation was used to calculate the specific surface area $\left(A_{\mathrm{BET}}\right)$. The Barrett Joyner Halenda $(\mathrm{BJH})$ method was used to calculate the average pore diameter and pore volume from the desorption branch of the isotherm. The contents of $\mathrm{Ni}$ and $\mathrm{P}$ were measured by a Bruker S4 Pioneer X-ray fluorescence (XRF) instrument. CO chemisorption was used to measure the density of exposed $\mathrm{Ni}$ sites of the catalysts, and $\mathrm{H}_{2}$ temperature-programmed desorption $\left(\mathrm{H}_{2}\right.$-TPD) and $\mathrm{NH}_{3}$ temperature-programmed desorption $\left(\mathrm{NH}_{3}\right.$-TPD) were used to measure the states of hydrogen species and the acidity of the catalysts, respectively. $\mathrm{CO}$ chemisorption, $\mathrm{H}_{2}$-TPD, and $\mathrm{NH}_{3}$-TPD were carried out in a homemade device and the procedures were same as those in previous work [15].

\subsection{Activity test}

The hydrogenolysis of glycerol was carried out in a stainless-steel fixed-bed reactor. For comparison, the hydrogenolysis of 1,2-PDO, the hydrogenation of acetol and the hydrogenolysis of glycol were also tested. The passivated $\mathrm{Ni}_{2} \mathrm{P} / \mathrm{SiO}_{2}$ was pre-reduced at $723 \mathrm{~K}$ for $40 \mathrm{~min}$ in a $\mathrm{H}_{2}$ flow (>99.9\%, $150 \mathrm{ml} / \mathrm{min}$ ), while $\mathrm{Ni} / \mathrm{SiO}_{2}$ was in-situ prepared via reduction with $\mathrm{H}_{2}$ at $723 \mathrm{~K}$ for $40 \mathrm{~min}$. After the reduction, the temperature and $\mathrm{H}_{2}$ pressure were adjusted to the desired values. The glycerol, 1,2-PDO, acetol 
or glycol aqueous solution was continuously fed to the reactor using a pump. The reactant mass concentration was $60 \%$. The liquid products were analyzed on an SP-3420 gas chromatograph equipped with an FID and a commercial PEG-20M capillary column. Gas products were analyzed by a 102 gas chromatograph equipped with a TCD and a TDX-101 packed column.

\section{Results and discussion}

\subsection{Catalyst characterization}

Figure 1 shows the XRD patterns of $\mathrm{Ni}_{2} \mathrm{P} / \mathrm{SiO}_{2}$ and $\mathrm{Ni} / \mathrm{SiO}_{2}$. Apart from the support, only a metallic Ni phase was detected in $\mathrm{Ni} / \mathrm{SiO}_{2}$ while only a $\mathrm{Ni}_{2} \mathrm{P}$ phase was detected in $\mathrm{Ni}_{2} \mathrm{P} / \mathrm{SiO}_{2}$. The average sizes of $\mathrm{Ni}_{2} \mathrm{P}$ and metallic Ni crystallites were 13.5 and $10.7 \mathrm{~nm}$ (Table 1), calculated with the Scherrer equation from the $\mathrm{Ni}_{2} \mathrm{P}(111)$ and $\mathrm{Ni}(111)$ peaks, respectively.

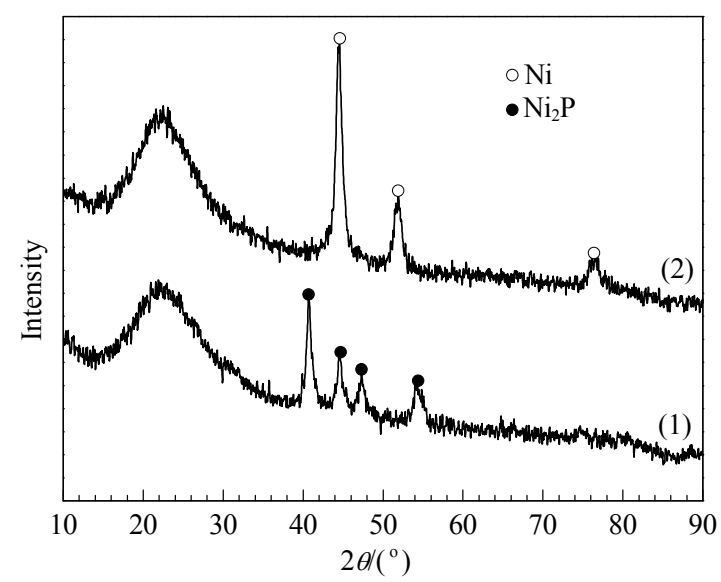

Fig. 1. XRD patterns of $\mathrm{Ni}_{2} \mathrm{P} / \mathrm{SiO}_{2}(1)$ and $\mathrm{Ni} / \mathrm{SiO}_{2}(2)$.

Table 1 shows the $\mathrm{Ni}$ and $\mathrm{P}$ contents and textural properties of $\mathrm{Ni}_{2} \mathrm{P} / \mathrm{SiO}_{2}$ and $\mathrm{Ni} / \mathrm{SiO}_{2}$. The $\mathrm{Ni}$ mass contents in $\mathrm{Ni} / \mathrm{SiO}_{2}$ and $\mathrm{Ni}_{2} \mathrm{P} / \mathrm{SiO}_{2}$ were $16.7 \%$ and $14.7 \%$, respectively. The Ni/P molar ratio in the $\mathrm{Ni}_{2} \mathrm{P} / \mathrm{SiO}_{2}$ was calculated as 1.6:1, which was higher than that $(1: 1)$ in the precursor and lower than that $(2: 1)$ in pure $\mathrm{Ni}_{2} \mathrm{P}$. This indicates that there was a $\mathrm{P}$ loss during the preparation of $\mathrm{Ni}_{2} \mathrm{P} / \mathrm{SiO}_{2}$ [16] and there were still excess, unreduced $\mathrm{P}$ species (such as $\mathrm{H}_{n} \mathrm{PO}_{4}{ }^{(3-n)-}$ and $\left.\mathrm{P}_{2} \mathrm{O}_{7}{ }^{4-}[17]\right)$ in the $\mathrm{Ni}_{2} \mathrm{P} / \mathrm{SiO}_{2}$. Compared with $\mathrm{Ni} / \mathrm{SiO}_{2}, \mathrm{Ni}_{2} \mathrm{P} / \mathrm{SiO}_{2}$ had a lower specific surface area and a smaller average pore diameter, and pore volume. This may be ascribed to its higher preparation temperature and the blockage of pores with the excess unreduced $\mathrm{P}$ species. In addition, the $\mathrm{CO}$ uptakes of $\mathrm{Ni}_{2} \mathrm{P} / \mathrm{SiO}_{2}$ and $\mathrm{Ni} / \mathrm{SiO}_{2}$ were 27 and $25 \mu \mathrm{mol} / \mathrm{g}$, respectively, indicating that $\mathrm{Ni} / \mathrm{SiO}_{2}$ and $\mathrm{Ni}_{2} \mathrm{P} / \mathrm{SiO}_{2}$ had similar densities of exposed $\mathrm{Ni}$ sites.

Figure 2 shows the $\mathrm{H}_{2}$-TPD profiles. Generally the peaks below $700 \mathrm{~K}$ are ascribed to the desorption of hydrogen species on the surface of the metal phase, while the peaks above $700 \mathrm{~K}$ are attributed to spilt-over hydrogen species [18]. $\mathrm{Ni}_{2} \mathrm{P} / \mathrm{SiO}_{2}$ had three desorption peaks below $700 \mathrm{~K}$, indicating that there were hydrogen species in different states adsorbed on the $\mathrm{Ni}_{2} \mathrm{P}$ particles. $\mathrm{Ni} / \mathrm{SiO}_{2}$ gave a distinct and a broad peak below $700 \mathrm{~K}$. Above $700 \mathrm{~K} \mathrm{Ni}_{2} \mathrm{P} / \mathrm{SiO}_{2}$ had more spilt-over hydrogen than $\mathrm{Ni} / \mathrm{SiO}_{2} \cdot \mathrm{Ni}_{2} \mathrm{P} / \mathrm{SiO}_{2}$ had a similar density of the exposed $\mathrm{Ni}$ sites as $\mathrm{Ni} / \mathrm{SiO}_{2}$ as measured by $\mathrm{CO}$ chemisorption while it yielded a much larger amount of desorbed $\mathrm{H}_{2}$ than $\mathrm{Ni} / \mathrm{SiO}_{2}$. This was likely due to the contribution of $\mathrm{P}-\mathrm{OH}$ groups on $\mathrm{Ni}_{2} \mathrm{P} / \mathrm{SiO}_{2}$ [15]. On one hand $\mathrm{P}-\mathrm{OH}$ groups could be formed on $\mathrm{Ni}_{2} \mathrm{P}$ particles via the passivation and re-reduction processes [13] and may have contributed to the $\mathrm{H}_{2}$ desorption below $700 \mathrm{~K}$. On the other hand $\mathrm{P}-\mathrm{OH}$ groups may exist in the unreduced $\mathrm{P}$ species on the support, which may account for the larger amount of spilt-over hydrogen on $\mathrm{Ni}_{2} \mathrm{P} / \mathrm{SiO}_{2}$. Indeed, it has been proposed that $-\mathrm{OH}$ groups (which also act as Brönsted acid sites) can stabilize spilt-over hydrogen [19].

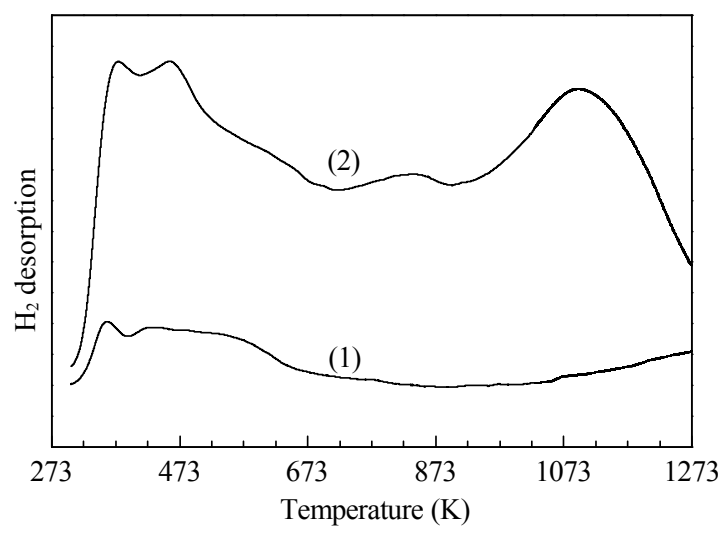

Fig. 2. $\mathrm{H}_{2}$-TPD profiles of $\mathrm{Ni} / \mathrm{SiO}_{2}(1)$ and $\mathrm{Ni}_{2} \mathrm{P} / \mathrm{SiO}_{2}(2)$.

Figure 3 shows the $\mathrm{NH}_{3}$-TPD profiles. $\mathrm{Ni} / \mathrm{SiO}_{2}$ had two peaks at 480 and $623 \mathrm{~K}$, while $\mathrm{Ni}_{2} \mathrm{P} / \mathrm{SiO}_{2}$ gave a main peak at $488 \mathrm{~K}$ with a shoulder peak at higher temperature. Obviously, $\mathrm{Ni}_{2} \mathrm{P} / \mathrm{SiO}_{2}$ had more acid sites than $\mathrm{Ni} / \mathrm{SiO}_{2}$, while the strength of acid sites on $\mathrm{Ni}_{2} \mathrm{P} / \mathrm{SiO}_{2}$ and $\mathrm{Ni} / \mathrm{SiO}_{2}$ was weak

Table $1 \mathrm{Ni}$ and $\mathrm{P}$ contents and textural properties of $\mathrm{Ni} / \mathrm{SiO}_{2}$ and $\mathrm{Ni}_{2} \mathrm{P} / \mathrm{SiO}_{2}$

\begin{tabular}{lccccccc}
\hline Sample & $\begin{array}{c}\text { Ni content } \\
(\%)\end{array}$ & $\begin{array}{c}\text { P content } \\
(\%)\end{array}$ & $\begin{array}{c}A_{\mathrm{BET}} / \\
\left(\mathrm{m}^{2} / \mathrm{g}\right)\end{array}$ & $\begin{array}{c}\text { Average pore diameter } \\
(\mathrm{nm})\end{array}$ & $\begin{array}{c}\text { Pore volume } \\
\left(\mathrm{cm}^{3} / \mathrm{g}\right)\end{array}$ & $\begin{array}{c}\text { CO uptake } \\
(\mu \mathrm{mol} / \mathrm{g})\end{array}$ & $\begin{array}{c}\text { Crystallite size } \\
(\mathrm{nm})\end{array}$ \\
\hline $\mathrm{Ni} / \mathrm{SiO}_{2}$ & 16.7 & - & 444 & 5.7 & 0.654 & 25 & 10.7 \\
$\mathrm{Ni}_{2} \mathrm{P} / \mathrm{SiO}_{2}$ & 14.7 & 4.8 & 356 & 4.9 & 0.514 & 27 & 13.5 \\
\hline
\end{tabular}




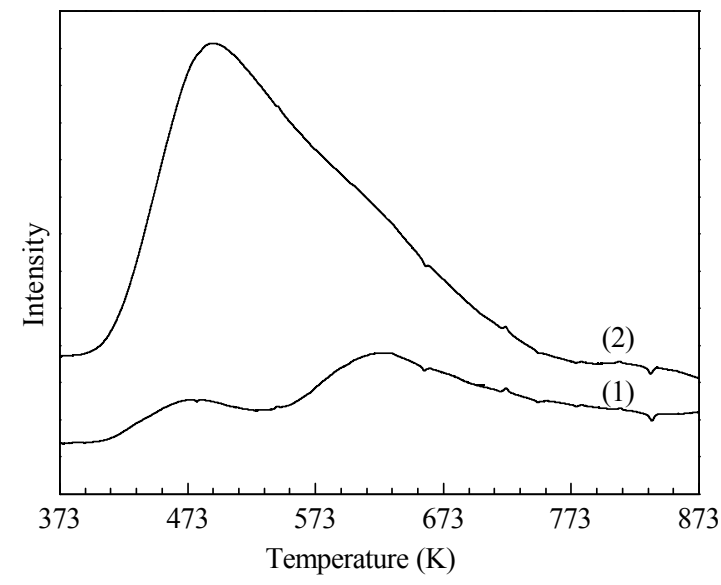

Fig. 3. $\mathrm{NH}_{3}-\mathrm{TPD}$ profiles of $\mathrm{Ni} / \mathrm{SiO}_{2}(1)$ and $\mathrm{Ni}_{2} \mathrm{P} / \mathrm{SiO}_{2}(2)$.

and medium. Base on peak areas the number of acid sites on $\mathrm{Ni}_{2} \mathrm{P} / \mathrm{SiO}_{2}$ was about three times as large as that on $\mathrm{Ni} / \mathrm{SiO}_{2}$. Using Fourier transform infrared (FT-IR) analysis with the probe molecule pyridine, Brönsted and Lewis acid sites have been detected on $\mathrm{Ni}_{2} \mathrm{P} / \mathrm{SiO}_{2}$ [13]. The Brönsted acid sites are attributed to $\mathrm{P}-\mathrm{OH}$ groups. The Lewis acid sites may be related to the $\mathrm{Ni}$ sites on the surface of $\mathrm{Ni}_{2} \mathrm{P}$ particles. As indicated by a density functional theory (DFT) calculation, the $\mathrm{Ni}-\mathrm{P}$ bond in $\mathrm{Ni}_{2} \mathrm{P}$ is covalent [20], while there is an electron transfer from $\mathrm{Ni}$ to $\mathrm{P}$ [14]. The electron-deficiency of $\mathrm{Ni}$ sites may account for the Lewis acidity of $\mathrm{Ni}_{2} \mathrm{P}$. This is not the case for the metallic Ni. Thus, the acidity of $\mathrm{Ni}_{2} \mathrm{P} / \mathrm{SiO}_{2}$ can ascribed to electron-deficient $\mathrm{Ni}$ sites (Lewis acid sites) and $\mathrm{P}-\mathrm{OH}$ groups (Brönsted acid sites) $[13,15]$, while that of $\mathrm{Ni} / \mathrm{SiO}_{2}$ is only due to the unreduced nickel silicate that leads to Lewis acidity [21]. Phosphorous may account for the larger amount of acid sites as well as surface hydrogen (including spilt-over one) on $\mathrm{Ni}_{2} \mathrm{P} / \mathrm{SiO}_{2}$.

\subsection{Catalytic performance of $\mathrm{Ni} / \mathrm{SiO}_{2}$ and $\mathrm{Ni}_{2} \mathrm{P} / \mathrm{SiO}_{2}$}

Table 2 shows the reactivity of $\mathrm{Ni} / \mathrm{SiO}_{2}$ and $\mathrm{Ni}_{2} \mathrm{P} / \mathrm{SiO}_{2}$ in different reactions. The glycerol conversions over $\mathrm{Ni}_{2} \mathrm{P} / \mathrm{SiO}_{2}$ and $\mathrm{Ni} / \mathrm{SiO}_{2}$ were $95.1 \%$ and $73.2 \%$ in hydrogenolysis of glycerol, respectively. Thus, $\mathrm{Ni}_{2} \mathrm{P} / \mathrm{SiO}_{2}$ was more active than $\mathrm{Ni} / \mathrm{SiO}_{2}$ in the hydrogenolysis of glycerol. Also, there was a remarkable difference in the product selectivities on $\mathrm{Ni}_{2} \mathrm{P} / \mathrm{SiO}_{2}$ and $\mathrm{Ni} / \mathrm{SiO}_{2}$. On $\mathrm{Ni}_{2} \mathrm{P} / \mathrm{SiO}_{2}$ the main products were 1,2-PDO and 1-propanol with selectivities of $85.9 \%$ and $7.2 \%$, respectively, and the total selectivity of glycol and ethanol was only about $2.3 \%$. On Ni/SiO 2 , however, the selectivity to $1,2-\mathrm{PDO}$ was only $49.9 \%$, while the selectivities for EG and ethanol were $30.4 \%$ and $12.8 \%$, respectively. In the effluent gas only $\mathrm{CH}_{4}$ was detected using $\mathrm{Ni} / \mathrm{SiO}_{2}$, while it was not produced over $\mathrm{Ni}_{2} \mathrm{P} / \mathrm{SiO}_{2}$. In addition neither $\mathrm{CO}$ nor $\mathrm{CO}_{2}$ was produced over $\mathrm{Ni} / \mathrm{SiO}_{2}$ and $\mathrm{Ni}_{2} \mathrm{P} / \mathrm{SiO}_{2}$. Clearly the cleavage of $\mathrm{C}-\mathrm{O}$ bonds mainly occurred on $\mathrm{Ni}_{2} \mathrm{P} / \mathrm{SiO}_{2}$ while the cleavage of both $\mathrm{C}-\mathrm{O}$ and $\mathrm{C}-\mathrm{C}$ bonds took place on $\mathrm{Ni} / \mathrm{SiO}_{2}$.

Table 2 Reactivity of $\mathrm{Ni} / \mathrm{SiO}_{2}$ and $\mathrm{Ni}_{2} \mathrm{P} / \mathrm{SiO}_{2}$ in different reactions

\begin{tabular}{|c|c|c|c|c|c|c|c|c|c|c|c|c|}
\hline \multirow{2}{*}{ Reaction } & \multicolumn{2}{|c|}{ Conversion $(\%)$} & \multicolumn{2}{|c|}{$S_{1,2-\mathrm{PDO}} / \%$} & \multicolumn{2}{|c|}{$S_{\mathrm{EG}} / \%$} & \multicolumn{2}{|c|}{$S_{\text {ethanol }} / \%$} & \multicolumn{2}{|c|}{$S_{1 \text {-propanol }} / \%$} & \multicolumn{2}{|c|}{$S_{\text {others }} / \%$} \\
\hline & $\mathrm{Ni} / \mathrm{SiO}_{2}$ & $\mathrm{Ni}_{2} \mathrm{P} / \mathrm{SiO}_{2}$ & $\mathrm{Ni} / \mathrm{SiO}_{2}$ & $\mathrm{Ni}_{2} \mathrm{P} / \mathrm{SiO}_{2}$ & $\mathrm{Ni} / \mathrm{SiO}_{2}$ & $\mathrm{Ni}_{2} \mathrm{P} / \mathrm{SiO}_{2}$ & $\mathrm{Ni} / \mathrm{SiO}_{2}$ & $\mathrm{Ni}_{2} \mathrm{P} / \mathrm{SiO}_{2}$ & $\mathrm{Ni} / \mathrm{SiO}_{2}$ & $\mathrm{Ni}_{2} \mathrm{P} / \mathrm{SiO}_{2}$ & $\mathrm{Ni} / \mathrm{SiO}_{2}$ & $\mathrm{Ni}_{2} \mathrm{P} / \mathrm{SiO}_{2}$ \\
\hline Glycerol hydrogenolysis & 73.2 & 95.1 & 49.9 & 85.9 & 30.4 & 1.3 & 12.8 & 1.0 & 1.4 & 7.2 & 5.5 & 4.6 \\
\hline 1,2-PDO hydrogenolysis & 62.9 & 23.7 & - & - & - & - & 93.4 & 4.4 & 4.6 & 94.6 & 2.0 & 1.0 \\
\hline EG hydrogenolysis & 46.5 & - & - & - & - & - & 18.1 & - & - & - & $81.9^{\mathrm{a}}$ & - \\
\hline
\end{tabular}

Reaction conditions: $493 \mathrm{~K}, 3.0 \mathrm{MPa}$, WHSV of $1.13 \mathrm{~h}^{-1}, \mathrm{H}_{2} /$ reactant molar ratio of 20.

${ }^{a}$ Methanol selectivity.

$S_{1,2-\mathrm{PDO}}$ : 1,2-PDO selectivity; $S_{\text {ethanol }}$ : ethanol selectivity; $S_{\mathrm{EG}}$ : glycol selectivity; $S_{1 \text {-propanol }}$ 1-propanol selectivity; Others: including methanol, acetol, 1,3-PDO, and 2-propanol.

As shown in Table $1 \mathrm{Ni} / \mathrm{SiO}_{2}$ had a larger specific surface area than $\mathrm{Ni}_{2} \mathrm{P} / \mathrm{SiO}_{2}$, and $\mathrm{Ni} / \mathrm{SiO}_{2}$ and $\mathrm{Ni}_{2} \mathrm{P} / \mathrm{SiO}_{2}$ had similar densities of exposed Ni sites. Thus, the higher activity of $\mathrm{Ni}_{2} \mathrm{P} / \mathrm{SiO}_{2}$ in the hydrogenolysis of glycerol and the different product selectivities on $\mathrm{Ni}_{2} \mathrm{P} / \mathrm{SiO}_{2}$ and $\mathrm{Ni} / \mathrm{SiO}$ should be related to other structural properties. As indicated by the $\mathrm{NH}_{3}$-TPD results (Fig. 3) $\mathrm{Ni}_{2} \mathrm{P} / \mathrm{SiO}_{2}$ possessed more acid sites than $\mathrm{Ni} / \mathrm{SiO}_{2}$. The acid sites can promote the dehydration of glycerol to form acetol that is then hydrogenated to 1,2-PDO. A similar promoting effect has also been proposed in the literatures [4-9]. Miyazawa et al. [4] proposed that compared with $\mathrm{Ru} / \mathrm{C}$ alone the combination of $\mathrm{Ru} / \mathrm{C}$ with an acid catalyst promoted the hydrogenolysis of glycerol and led to the increased selectivity for 1,2-PDO and the decreased selectivity for EG. Zhao et al. [9] reported that unsupported Ni powders can catalyze the hydrogenolysis of glycerol to form 1,2-PDO and EG. This indicates that metallic $\mathrm{Ni}$ can catalyze the cleavage of both $\mathrm{C}-\mathrm{C}$ and $\mathrm{C}-\mathrm{O}$ bonds. When metallic Ni was supported on $\mathrm{NaX}$ zeolite, the selectivity for 1,2-PDO was enhanced and the selectivity for EG was decreased. This was attributed to the acidity of $\mathrm{NaX}$ that catalyzed the dehydration of glycerol to acetol [9]. Ma 
et al. [6] and Balaraju et al. [7] have also proposed that there is a synergism between acid and metal sites in the hydrogenolysis of glycerol (via dehydration and hydrogenation) to form 1,2-PDO. Different from supported metallic catalysts whose acidity is derived from the supports, $\mathrm{Ni}_{2} \mathrm{P}$ can provide itself acid sites as well as Ni sites, and the synergism between acid and Ni sites for the hydrogenolysis of glycerol to form 1,2-PDO may be more effective. In addition, following the suggestion of Liu et al. [22] that $\mathrm{O}$ atom preferentially interacted with the $\mathrm{P}$ atom rather than the $\mathrm{Ni}$ atom on $\mathrm{Ni}_{2} \mathrm{P}(001)$, we speculate that the interaction between the $\mathrm{P}$ sites in $\mathrm{Ni}_{2} \mathrm{P}$ and the $\mathrm{O}$ atom in glycerol might also favor the activation and cleavage of $\mathrm{C}-\mathrm{O}$ bonds. Therefore, the more acidic sites and the preferential interaction of $\mathrm{P}$ with $\mathrm{O}$ may account for the higher activity of $\mathrm{Ni}_{2} \mathrm{P} / \mathrm{SiO}_{2}$ in the hydrogenolysis of glycerol in comparison with that of $\mathrm{Ni} / \mathrm{SiO}_{2}$. Moreover, the acidity may restrain the cleavage of $\mathrm{C}-\mathrm{C}$ bonds through promoting the cleavage of $\mathrm{C}-\mathrm{O}$ bonds. In other words, there may be a competition of cleavage between the $\mathrm{C}-\mathrm{O}$ bonds and $\mathrm{C}-\mathrm{C}$ bonds. Metallic $\mathrm{Ni}$ is active for the cleavages of both $\mathrm{C}-\mathrm{C}$ and $\mathrm{C}-\mathrm{O}$ bonds, while the acidity can promote the cleavage of $\mathrm{C}-\mathrm{O}$ bonds via dehydration forming acetol that can actively be hydrogenated (shown below). However, metallic Ni or Ru catalysts still gave a certain amount of EG and ethanol even if they were combined with acidic components $[4,9]$. Therefore the restraining effect of acidity on the cleavage of $\mathrm{C}-\mathrm{C}$ bonds is limited. Thus, the smaller activity of $\mathrm{Ni}_{2} \mathrm{P} / \mathrm{SiO}_{2}$ compared with that of $\mathrm{Ni} / \mathrm{SiO}_{2}$ for the cleavage of $\mathrm{C}-\mathrm{C}$ bonds may not be only attributed to the role of the acidity. It is also likely related to the different structural properties of bulk $\mathrm{Ni}_{2} \mathrm{P}$ and $\mathrm{Ni}$.

It is known that the $\mathrm{Ni}$ site in $\mathrm{Ni}_{2} \mathrm{P}$ has lower electron density than that in metallic $\mathrm{Ni}$, and the ensemble effect of $\mathrm{P}$ leads to the increase of the $\mathrm{Ni}-\mathrm{Ni}$ distance [17], all of which may be related to the lower activity of $\mathrm{Ni}_{2} \mathrm{P} / \mathrm{SiO}_{2}$ for the cleavage of $\mathrm{C}-\mathrm{C}$ bonds. This supposition is reasonable since the electronic and geometrical property of catalysts may influence the adsorption of glycerol and so influence the selectivity to the cleavage of $\mathrm{C}-\mathrm{O}$ and $\mathrm{C}-\mathrm{C}$ bonds. Two series of experiments were designed to test the supposition that $\mathrm{Ni}_{2} \mathrm{P}$ is in nature less active than metallic $\mathrm{Ni}$ for the cleavage of $\mathrm{C}-\mathrm{C}$ bonds: (1) The effects of temperature and $\mathrm{H}_{2}$ pressure on the performance of $\mathrm{Ni}_{2} \mathrm{P} / \mathrm{SiO}_{2}$; (2) The hydrogenation of acetol and hydrogenolysis of 1,2-PDO over $\mathrm{Ni} / \mathrm{SiO}_{2}$ and $\mathrm{Ni}_{2} \mathrm{P} / \mathrm{SiO}_{2}$.

It is well known that the cleavage of $\mathrm{C}-\mathrm{C}$ bonds is thermodynamically favored at high temperature and $\mathrm{H}_{2}$ pressure. However, as shown in Figs. 4 and 5, the total selectivity for EG and ethanol $\left(S_{\mathrm{C} 2}\right)$ did not change obviously as the temperature and $\mathrm{H}_{2}$ pressure increased, while the selectivity for 1,2-PDO decreased and the selectivity for 1-propanol in-

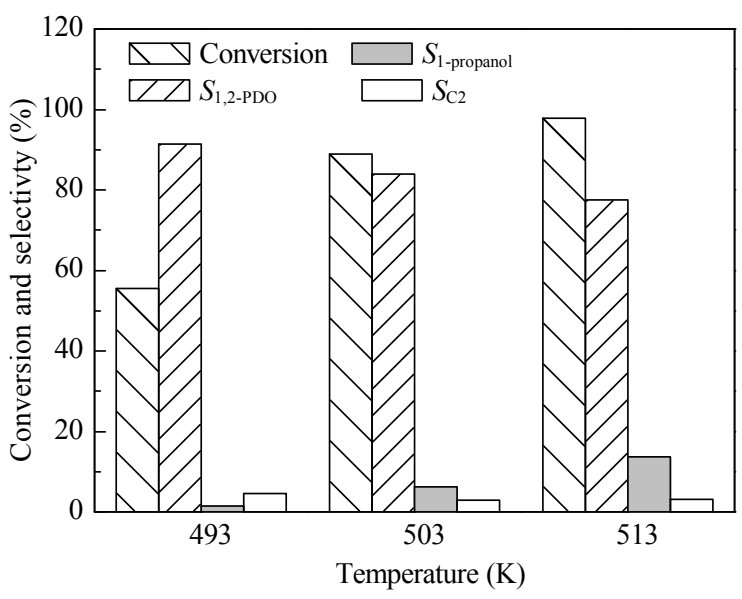

Fig. 4. Effect of temperature on the reactivity of $\mathrm{Ni}_{2} \mathrm{P} / \mathrm{SiO}_{2}$ in hydrogenolysis of glycerol. Reaction conditions: 3.0 MPa, glycerol WHSV of $1.73 \mathrm{~h}^{-1}, \mathrm{H}_{2} /$ glycerol molar ratio of 20 .

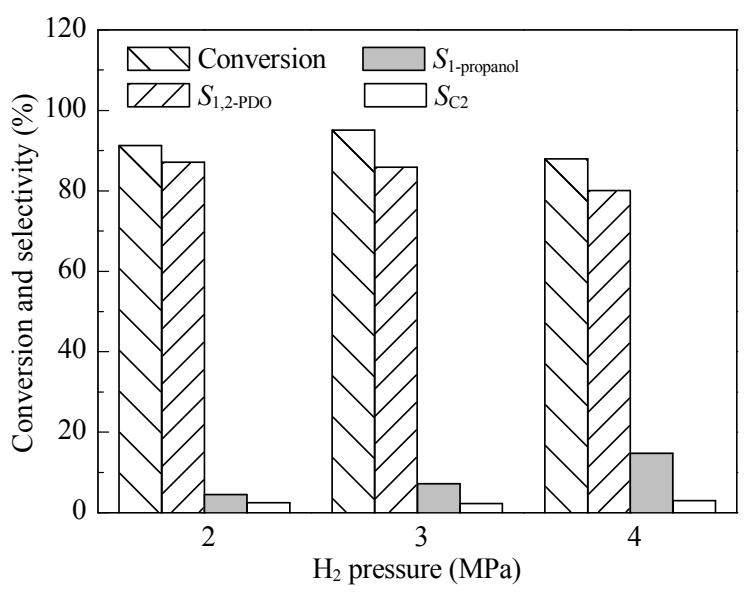

Fig. 5. Effect of $\mathrm{H}_{2}$ pressure on reactivity of $\mathrm{Ni}_{2} \mathrm{P} / \mathrm{SiO}_{2}$ in hydrogenolysis of glycerol. Reaction conditions: $493 \mathrm{~K}$, glycerol WHSV of $1.13 \mathrm{~h}^{-1}, \mathrm{H}_{2} /$ glycerol molar ratio of 20 .

creased. This indicates that the increased temperature and $\mathrm{H}_{2}$ pressure mainly promoted the further hydrogenolysis of 1,2-PDO to 1-propanol via the cleavage of the $\mathrm{C}-\mathrm{O}$ bond and had less effect on the cleavage of the $\mathrm{C}-\mathrm{C}$ bond. However, this case is greatly different from that of Ni-based catalysts combined with acidic sites (for example $\mathrm{Ni} / \mathrm{NaX}$ [9], $\mathrm{Ni} / \mathrm{SiO}_{2}$, and $\mathrm{Ni} / \mathrm{Al}_{2} \mathrm{O}_{3}$ [10]), on which the cleavage of the $\mathrm{C}-\mathrm{C}$ bond was greatly promoted by increased temperature and $\mathrm{H}_{2}$ pressure leading to formation of degradation products.

The reactivities of $\mathrm{Ni} / \mathrm{SiO}_{2}$ and $\mathrm{Ni}_{2} \mathrm{P} / \mathrm{SiO}_{2}$ in the hydrogenation of acetol and hydrogenolysis of 1,2-PDO are shown in Table 2. Acetol was the intermediate product derived from the dehydration of glycerol. In the hydrogenation of acetol, acetol was almost completely converted over both $\mathrm{Ni} / \mathrm{SiO}_{2}$ and $\mathrm{Ni}_{2} \mathrm{P} / \mathrm{SiO}_{2}$, indicating that acetol was a very active intermediate. However, there was also a difference in the product distribution on $\mathrm{Ni} / \mathrm{SiO}_{2}$ and $\mathrm{Ni}_{2} \mathrm{P} / \mathrm{SiO}_{2}$. 
$\mathrm{Ni}_{2} \mathrm{P} / \mathrm{SiO}_{2}$ gave 1,2-PDO and 1-propanol with selectivities of $84.3 \%$ and $13.2 \%$, respectively, while $\mathrm{Ni} / \mathrm{SiO}_{2}$ gave 1,2-PDO and ethanol with selectivities of $13.1 \%$ and $78.8 \%$, respectively. The conversions of 1,2-PDO over $\mathrm{Ni} / \mathrm{SiO}_{2}$ and $\mathrm{Ni}_{2} \mathrm{P} / \mathrm{SiO}_{2}$ were $62.9 \%$ and $23.7 \%$, respectively, in the hydrogenolysis of 1,2-PDO. Thus, $\mathrm{Ni} / \mathrm{SiO}_{2}$ was more active than $\mathrm{Ni}_{2} \mathrm{P} / \mathrm{SiO}_{2}$ in the hydrogenolysis of 1,2-PDO. $\mathrm{Ni}_{2} \mathrm{P} / \mathrm{SiO}_{2}$ gave 1-propanol with a selectivity of $94.6 \%$, while $\mathrm{Ni} / \mathrm{SiO}_{2}$ gave ethanol with a selectivity of $93.4 \%$. Clearly, in the reactions above the main product on $\mathrm{Ni} / \mathrm{SiO}_{2}$ was ethanol derived from the cleavage of the $\mathrm{C}-\mathrm{C}$ bond, while $\mathrm{Ni}_{2} \mathrm{P} / \mathrm{SiO}_{2}$ mainly gave the products derived from the cleavage of the $\mathrm{C}-\mathrm{O}$ bond. This further indicates that $\mathrm{Ni} / \mathrm{SiO}_{2}$ had much higher activity for the cleavage of $\mathrm{C}-\mathrm{C}$ bonds than $\mathrm{Ni}_{2} \mathrm{P} / \mathrm{SiO}_{2}$. A high activity of Ni-based catalysts for the cleavage of $\mathrm{C}-\mathrm{C}$ bonds has also been found in other reactions such as the hydrogenolysis of saturated hydrocarbons [23] and conversion of triglyceride to hydrocarbons [24]. This higher activity of metallic Ni for the cleavage of $\mathrm{C}-\mathrm{C}$ bonds might account for the higher conversion of 1,2-PDO over $\mathrm{Ni} / \mathrm{SiO}_{2}$ than over $\mathrm{Ni}_{2} \mathrm{P} / \mathrm{SiO}_{2}$. In other words, the conversion of 1,2-PDO on $\mathrm{Ni} / \mathrm{SiO}_{2}$ was realized through the cleavage of both $\mathrm{C}-\mathrm{C}$ and $\mathrm{C}-\mathrm{O}$ bonds (especially the cleavage of $\mathrm{C}-\mathrm{C}$ bonds), while conversion on $\mathrm{Ni}_{2} \mathrm{P} / \mathrm{SiO}_{2}$ was mainly realized through the cleavage of $\mathrm{C}-\mathrm{O}$ bonds. Also, the hydrogenolysis of 1,2-PDO is more difficult than that of glycerol [4]. Thus, the higher activity of $\mathrm{Ni}_{2} \mathrm{P} / \mathrm{SiO}_{2}$ in the hydrogenolysis of glycerol and lower activity in the hydrogenolysis of 1,2-PDO compared with those of $\mathrm{Ni} / \mathrm{SiO}_{2}$ also indicates that $\mathrm{Ni} / \mathrm{SiO}_{2}$ had a much higher activity for the cleavage of the $\mathrm{C}-\mathrm{C}$ bond than $\mathrm{Ni}_{2} \mathrm{P} / \mathrm{SiO}_{2}$. As another evidence, the hydrogenolysis of $\mathrm{EG}$ on $\mathrm{Ni} / \mathrm{SiO}_{2}$ was also tested and the main product was methanol derived form the cleavage of the $\mathrm{C}-\mathrm{C}$ bond (Table 2). Additionally, it is well known that strong acidity of catalysts also contributes to the cleavage of $\mathrm{C}-\mathrm{C}$ bonds [25]. Based on the above results we speculate that the acidity of $\mathrm{Ni}_{2} \mathrm{P}$ might be too weak to catalyze the cleavage of $\mathrm{C}-\mathrm{C}$ bonds. Again, $\mathrm{Ni} / \mathrm{SiO}_{2}$ had a much smaller amount of acid sites than $\mathrm{Ni}_{2} \mathrm{P} / \mathrm{SiO}_{2}$, while it showed much higher activity for the cleavage of $\mathrm{C}-\mathrm{C}$ bonds. Therefore, $\mathrm{Ni}_{2} \mathrm{P} / \mathrm{SiO}_{2}$ is by nature less active than $\mathrm{Ni} / \mathrm{SiO}_{2}$ for the cleavage of $\mathrm{C}-\mathrm{C}$ bonds which is probably related to its electronic and geometrical properties.

The reaction mechanism of the glycerol hydrogenolysis has been reported [7,10]. Applied to the present work the main routes on $\mathrm{Ni}_{2} \mathrm{P} / \mathrm{SiO}_{2}$ and $\mathrm{Ni} / \mathrm{SiO}_{2}$ are presented in Scheme 1. On $\mathrm{Ni}_{2} \mathrm{P} / \mathrm{SiO}_{2}$ glycerol is mainly converted via the following successive steps: dehydration of glycerol to form acetol on acid sites; hydrogenation of acetol to form 1,2-PDO on metal sites; hydrogenolysis (dehydration/hydrogenation) of 1,2-PDO to 1-propanol. Apart from the above steps there occurred other reactions on $\mathrm{Ni} / \mathrm{SiO}_{2}$ :

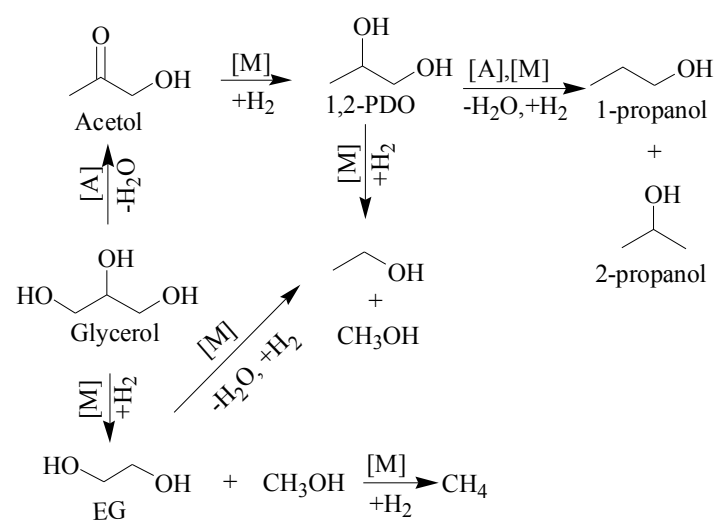

[M]: Metal site; [A]: Acid site

Scheme 1. Reaction pathways of glycerol hydrogenolysis.

cleavage of the $\mathrm{C}-\mathrm{C}$ bond in glycerol to form EG and methanol; hydrogenolysis of 1,2-PDO and EG to form ethanol and methanol; hydrogenation of methanol to form methane. Indeed, methane was formed over $\mathrm{Ni} / \mathrm{SiO}_{2}$ in the hydrogenolysis of glycerol, 1,2-PDO, and EG and the hydrogenation of acetol but was not over $\mathrm{Ni}_{2} \mathrm{P} / \mathrm{SiO}_{2}$.

\section{Conclusions}

The higher activity of $\mathrm{Ni}_{2} \mathrm{P} / \mathrm{SiO}_{2}$ than $\mathrm{Ni} / \mathrm{SiO}_{2}$ in the hydrogenolysis of glycerol is attributed to a synergism between acid sites $(\mathrm{P}-\mathrm{OH})$ and the metal sites $(\mathrm{Ni})$. Glycerol was dehydrated to acetol on acid sites while acetol was hydrogenated to 1,2-propanediol (1,2-PDO) on $\mathrm{Ni}$ sites. $\mathrm{Ni}_{2} \mathrm{P} / \mathrm{SiO}_{2}$ had higher activity for the cleavage of $\mathrm{C}-\mathrm{O}$ bonds and lower activity for the cleavage of $\mathrm{C}-\mathrm{C}$ bonds than $\mathrm{Ni} / \mathrm{SiO}_{2}$ not only in the hydrogenolysis of glycerol but also in the hydrogenation of acetol and the hydrogenolysis of 1,2-PDO. The former is ascribed to its acidity while the latter may mainly be related to its electronic and geometrical properties.

\section{References}

1 Corma A, Iborra S, Velty A. Chem Rev, 2007, 107: 2411

2 Behr A, Eilting J, Irawadi K, Leschinski J, Lindner F. Green Chem, 2008, 10: 13

3 Zheng Y, Chen X, Shen Y. Chem Rev, 2008, 108: 5253

4 Miyazawa T, Kusunoki Y, Kunimori K, Tomishige K. J Catal, 2006, 240: 213

5 Maris E P, Davis R J. J Catal, 2007, 249: 328

6 马兰, 李宇明, 贺德华. 催化学报 (Ma L, Li Y M, He D H. Chin J Catal), 2011, 32: 872

7 Balaraju M, Rekha V, Sai Prasad P S, Prabhavathi Devi B L A, Prasad R B N, Lingaiah N. Appl Catal A, 2009, 354: 82

8 冯建, 熊伟, 贾云, 王金波, 刘德容, 陈华, 李贤均. 催化学 报 (Feng J, Xiong W, Jia Y, Wang J B, Liu D R, Chen H, Li X 
J. Chin J Catal), 2011, 32: 1545

9 Zhao J, Yu W Q, Chen C, Miao H, Ma H, Xu J. Catal Lett, 2010, 134: 184

10 van Ryneveld E, Mahomed A S, van Heerden P S, Green M J, Friedrich H B. Green Chem, 2011, 13: 1819

11 Yu W Q, Zhao J, Ma H, Miao H, Song Q, Xu J. Appl Catal A, 2010, 383: 73

12 Akiyama M, Sato S, Takahashi R, Inui K, Yokota M. Appl Catal A, 2009, 371: 60

13 Lee Y K, Oyama S T. J Catal, 2006, 239: 376

14 Sawhill S J, Layman K A, Van Wyk D R, Engelhard M H, Wang Ch M, Bussell M E. J Catal, 2005, 231: 300

15 Li K L, Wang R J, Chen J X. Energy Fuels, 2011, 25: 854

16 Oyama S T, Wang X, Lee Y K, Chun W J. J Catal, 2004, 221: 263

17 Stinner C, Tang Z, Haouas M, Weber T, Prins R. J Catal, 2002,
208: 456

18 Arai M, Fukushima M, Nishiyama Y. Appl Surf Sci, 1996, 99: 145

19 Conner W C, Falconer J L. Chem Rev, 1995, 95: 759

20 Liu P, Rodriguez J A, Asakura T, Gomes J, Nakamura K. J Phys Chem B, 2005, 109: 4575

21 Hadjiivanov K, Mihaylov M, Klissurski D, Stefanov P, Abadjieva N, Vassileva E, Mintchevz L. J Catal, 1999, 185: 314

22 Liu P, Rodriguez J A, Takahashi Y, Nakamura K. J Catal, 2009, 262: 294

23 Leclercq G, Leclercq L, Bouleau L M, Pietrzyk S, Maurel R. $J$ Catal, 1984, 88: 8

24 Morgan T, Grubb D, Santillan-Jimenez E, Crocker M. Top Catal, 2010, 53: 820

25 Okumura K, Tomiyama T, Morishita N, Sanada T, Kamiguchi K, Katada N, Niwa M. Appl Catal A, 2011, 405: 8 